\title{
Preclinical Elucidation of Recombinant Humanized Anti-PD-1 Monoclonal Antibody (TA1718-B) Pharmacokinetics in Cynomolgus Monkeys, Rats, and Colon Cancer Humanized Mice
}

\section{Li-li Zhao}

Lunan pharmaceutical group Co. Ltd.

\section{Yun-gang Lv}

Shenzhen University General Hospital

\section{Lan-fang Li}

Lunan pharmaceutical group Co. LTd.

\section{Zeng-tian Liu}

Lunan pharmaceutical group Co. LTd.

\section{Dong Ma}

Lunan pharmaceutical group Co. LTd.

\section{Gui-min Zhang}

Shandong new time pharmaceutical Co. LTd.

\section{Zhong Liu}

Lunan pharmaceutical group Co. LTd.

\section{Yu-shan Ren}

Lunan pharmaceutical group Co. LTd.

Jie Li ( $\sim$ lijie02@lunan.cn)

Lunan pharmaceutical group Co. LTd.

Research article

Keywords: programmed cell death protein 1, TA1718-B, cancer immunotherapy, pharmacokinetics

Posted Date: August 27th, 2019

DOI: https://doi.org/10.21203/rs.2.13613/v1

License: (1) This work is licensed under a Creative Commons Attribution 4.0 International License. Read Full License 


\section{Abstract}

[EXSCINDED] Abstract Background PD-1 monoclonal antibodies (mAbs) are widely applicated in clinical as therapeutic strategy for multiple types of cancer. TA1718-B, a novel PD-1 mAb, is now entering clinical phase I.Methods In present study, the preclinical pharmacokinetic (PK) properties of TA1718-B were investigatedviavarious experiments in animal species. In plasma kinetic studies, cynomolgus monkeys underwent either single $(1,3$, and $10 \mathrm{mg} / \mathrm{kg}$ ) or repeat (4-times, $3 \mathrm{mg} / \mathrm{kg}$ ) intravenous injection and plasma were collected in different time points and detected by ELISA. Tissue distributions were performed in MC38 colon cancer humanizedmice. The excretion of TA1718-B was evaluated in rats.Results TA1718-B exhibited long T1/2 (from 97 to $136 \mathrm{hrs)} \mathrm{and} \mathrm{low} \mathrm{clearance} \mathrm{(Cl)} \mathrm{(from} 0.25$ to 0.38 $\mathrm{ml} / \mathrm{h} / \mathrm{kg}$ ) after intravenous single injection in cynomolgus monkeys. And 4-time continuous injections were not resulted in significant drug accumulation. However, both two drug delivery ways resulted in high anti-drug antibody (ADA) positive rates. The tissue distributions of TA1718-B were widely (almost in all tissues) and higher in serum, ovary, lung, tumorthan the other tissues in MC38 colon cancer humanized mice. The excretion of TA1718-B in rats were mainly metabolized and eliminated through proteolytic degradation.Radiopharmaceuticals in urine mainly existed in the form of proteolytic degradationfrom the data.Conclusion This systematic investigation of pharmacokinetic profiles of TA1718-B supplies basis for clinical trials and need to be further studied in Phase I clinical trial.

\section{Background}

In human, tumors occurrence commonly caused by genetic and epigenetic aberrations and produced altered antigenic profiles which can be selectively recognized by the adaptive immune response [1]. Between host and tumor, a dynamic interaction existed and evasion of immune recognition ability of the tumor directly determines the clinical course of the disease [2,3]. Cancer immunotherapy, also called immuno-oncology, is an anti-tumor therapeutic strategy which could improve the organic natural ability to fight cancer via using artificial agents (such as monoclonal antibodies, lymphocytes and cytokines) to stimulate the immune system [4-6]. The objective of tumor immunotherapy is to increase the specific immune response of tumor specific $\mathrm{CD} 4^{+}$and $\mathrm{CD} 8^{+} \mathrm{T}$ cell. And effective immunotherapeutic strategies are designed to enhance endogenous anti-tumor responses, such as cancer vaccines, which are far less successful $[7,8]$. In recent years, checkpoint blockade-based cancer immunotherapy is a research hotspot [9-11]. Immune checkpoints consist with a group of molecules which are targets for cancer immunotherapy because of their potential protective effects on tumors to get rid of immune system's attacks [12]. Checkpoint blockage such as obstructing CTLA-4 and PD-1/PDL-1 are currently approved for using in multiple types of cancer [13-16].

The initial clinical trial results of first PD-1 antibody (Nivolumab, Bristol-Myers Squibb Co., Inc.) were published in 2010 [12] and approved in 2014 for treating melanoma, lung cancer, kidney cancer, bladder cancer, head and neck cancer, and Hodgkin's lymphoma. Subsequently, another PD-1 inhibitor (Pembrolizumab, Merck \& Co., Inc.) was approved to treat melanoma and lung cancer by the FDA in 2014 [17]. Although several PD-1 monoclonal antibodies were approved by FDA and related pharmacokinetics 
studies are researched well, TA1718-B is a novel PD-1 mAb, lacking of drug metabolism and tissue distribution data. Therefore, to supply basis for clinical trials, PK parameters and biodistribution are evaluated.

Although numerous studies have discovered multiple pharmacological and extensively therapeutic activities of PD-1 monoclonal antibody, systematic evaluation of its pharmacokinetic characteristics are still limited. TA1718-B, a novel recombinant humanized anti-PD-1 monoclonal antibody was researched and developed independently by Lunan Pharmaceutical Group Co. Ltd.. The preclinical pharmacological studies of TA1718-B have been performed and applied for clinical trials. In current report, the plasma pharmacokinetic parameters, tissue distributions and excretion of TA1718-B were investigated in cynomolgus monkeys, MC38 colon cancer humanized mice and SD rats.

\section{Methods}

\section{Chemicals and Reagents}

Recombinant humanized anti PD-1 monoclonal antibody injection (TA1718-B, 25 mg/ml; purity, 99.7\%, determined by molecular exclusion chromatography) was obtained from National Engineering Laboratory of High Level Expression in Mammalian Cells (Lunan Pharmaceutical Group Co. Ltd, Linyi, Shan Dong province, China). $0.9 \%$ sodium chloride injection (vehicle) was from Shandong Kelun Pharmaceutical Co. Ltd. (Binzhou, Shandong, China). ${ }^{125}$ I-TA1718-B was supplied by MITRO Biotech Co. Ltd. (Nanjing, Jiangsu Province, China).

\section{Ethics}

All animal experiments were complied with the ARRIVE guidelines and carried out in accordance with the National Institutes of Health guide for the care and use of Laboratory animals (AARIVE guidelines checklist). All the animal including rats, mice and monkeys experiments were approved by the Institutional Animal Care and Use Committees (IACUC) of MITRO Biotech Co. Ltd., Shanghai Inno Star Bio-Tech Co. Ltd. in the contracts, respectively, and followed the "3Rs" rule (Reduction, Refinement, and Replacement).

\section{Pharmacokinetics study}

For PK study, 24 cynomolgus monkeys (12 male/12 female, 2.4-3.1 kg, 2-4.5 years old) were supplied by Guangxi Guidong primate development experiment Co. Ltd. (Wuzhou, Guangxi Zhuang Autonomous Region, China) randomly divided into 4 groups. The animals were weighed before eating during the adaptation period. The animals were divided into two groups according to sex, and then the same sex animals were randomly assigned to four groups according to body weight. During the whole experiment 
period, all animals received clinical observation including injection site, respiratory, exercise, urinary and behavioral changes. To minimize the harm monkeys, noise in monkey room was controlled and environmental factors were according to guidelines described in the guide to the care and use of experimental animals (Canadian Council on Animal Care, 1993).

For single administration study, animals were intravenously injected with 1, 3, and $10 \mathrm{mg} / \mathrm{kg}$ TA1718-B. Before $(0 \mathrm{~h})$ and after drug injection $(0.25,0.5,2,8,24,72,120,168,240,336,504,672,840$, and 1008 $\mathrm{hrs}), 1 \mathrm{ml}$ of the inguinal vein blood were harvested and stored at $-80^{\circ} \mathrm{C}$.

For repeated administration study, all animals were underwent $3 \mathrm{mg} / \mathrm{kg}$ i.v injection of TA1718-B, once a week, for 4 weeks. Before $(0 \mathrm{~h})$ and after first drug injection $(0.25,0.5,2,8,24,72,120,168 \mathrm{hrs}), 0.5 \mathrm{~h}$ before and after the second and third drug injection, before and $0.25,0.5,2,8,24,72,120,168$, and 240 hrs after the last (fourth) drug injection, $1 \mathrm{ml}$ of the inguinal vein blood were obtained and stored at -80 ${ }^{\circ} \mathrm{C}$.

The plasma samples were centrifuged at $4000 \mathrm{rpm}$ for $10 \mathrm{~min}$ at $4{ }^{\circ} \mathrm{C}$ to obtain the supernatant. The concentrations of TA1718-B in plasma were detected by ELISA.

\section{Immunogenicity assay}

To verify whether single or repeat injection resulted in immunogenicity reaction, before drug administration ( $0 \mathrm{~h}$ ), and $336,504,672,840,1008 \mathrm{hrs}$ after single injection, and $336 \mathrm{hrs}$ (before the third drug injection), before and $336 \mathrm{hrs}$ after the last drug delivery, $1 \mathrm{ml}$ of the inguinal vein blood were obtained and centrifuged at $4000 \mathrm{rpm}$ for $10 \mathrm{~min}$ at $4{ }^{\circ} \mathrm{C}$ to obtain the supernatant. Immunogenicity assay was performed by ELISA.

\section{Tissue distribution study}

24 MC38 colon cancer humanized mice (12 males/12 females) were purchased from Beijing Biocytogen Co. Ltd. (Beijing, China) for tissue distribution study. All animals were housed in SPF level barrier animal room of MITRO Biotech Co., Ltd. (Nanjing, Jiangsu Province, China) for 3 days' quarantine and then entering the project test. Animals were acclimatized to a controlled temperature $\left(23 \pm 2^{\circ} \mathrm{C}\right)$ and maintained under a 12/12-h light/dark cycle. The animals were supplied with pellet chow and water ad libitum. Before drug delivery, mice were intragastric injected (i.g) with $1 \%$ potassium iodide (KI) for blocking thyroid, and $0.01 \% \mathrm{KI}$ solution was drunk during the whole experiment. All mice were i.v injected with $3 \mathrm{mg} / \mathrm{kg}{ }^{125} \mathrm{I}$-TA1718-B (20 $\pm 10 \mu$ Ci peer mouse). 2, 96, 168, and $240 \mathrm{hrs}$ after drug injection, tissues including heart, liver, spleen, lung, kidney, stomach, intestine, gonad (testis and ovary), brain, fat, skeletal muscle, femur, tumor, mesenteric lymph node, thyroid, urine and serum were collected. All samples' total and sedimentary radioactivity were detected by $\mathrm{y}$-ray counter and converted to specific activity to 
calculate the concentration of radiopharmaceutical in tissues. To minimize suffering, mice were anaesthetized by intravenous injection of $1 \%$ sodium pentobarbital for tissue collection and euthanized by blood letting after anaesthesia .

\section{Excretion study}

6 SD rats (3 male/3 female, 5-7 weeks, 200-250 g) were purchased from JOINN Laboratories (Suzhou, Jiangsu Province, China) for urine and feces excretion experiments. 6 bile duct intubation model rats (3 male/3 female, 180-200 g) were purchased from Beijing Vital River Laboratory Animal Technology Co. Ltd. (Beijing, China) for bile excretion experiment. All animals were housed in SPF level barrier animal room of MITRO Biotech Co. Ltd. (Nanjing, Jiangsu Province, China) for 3 days' quarantine and then entering the project test. Animals were acclimatized to a controlled temperature $\left(23 \pm 2^{\circ} \mathrm{C}\right)$ and maintained under a 12/12-h light/dark cycle. The animals were supplied with pellet chow and water ad libitum. Before drug delivery, mice were intragastric injected (i.g) with $1 \% \mathrm{KI}$ to block thyroid, and $0.01 \% \mathrm{KI}$ solution was drunk during the whole experiment. All rats were i.v injected with $3 \mathrm{mg} / \mathrm{kg}^{125} \mathrm{I-TA} 1718-\mathrm{B}$ (20 $\pm 10 \mu \mathrm{Ci}$ per rat). After drug injection, urine and faces of SD rats were collected from $0-8,8-24,24-48,48$ $96,96-168,168-336,336-504,504-672,672-840$ hrs, bile of bile duct intubation model rats were collected from $0-4,4-8,8-24,24-48 \mathrm{hrs}$. Serum and urine samples of experimental animals with tissue distribution (1 male and 1 female at each time point) were prepared and separated for molecular exclusion HPLC detection. All samples' radioactivity was detected by $\mathrm{Y}$-ray counter and the cumulative excretion rates were calculated. To minimize suffering, rats were anaesthetized by intravenous injection of $2 \%$ sodium pentobarbital (Sigma, Louis, MO, USA) for animal operation throughout the experiment process.

\section{Method Validation}

\section{Preparation of Standard and QC Solutions}

TA1718-B was dissolved in cynomolgus monkey's serum in a series concentration $(8.000,4.444,2.469$, $1.372,0.762,0.423,0.235,0.131,0.073$ and $0 \mu \mathrm{g} / \mathrm{ml}$ ) as standard solutions. The QC solutions were prepared by cynomolgus monkey's serum and dissolved in $0.25 \mu \mathrm{g} / \mathrm{ml}$ (LQC), $0.70 \mu \mathrm{g} / \mathrm{ml}$ (MQC), and 3.5 $\mu \mathrm{g} / \mathrm{ml}(\mathrm{HQC})$, respectively.

\section{Linearity, Accuracy, and Precision}

The calibration curves were established from the peak area of each standard solution against the nominal concentrations using eight level non-zero standards and a linearly weighed $(1 / x)$ least squares regression model. The calibration curve required a correlation coefficient $\left(R^{2}\right)$ of 0.99 or better. 
Method accuracy was estimated by calculating the percent deviation observed in the analysis of quality control (QC) samples and expressed as relative error. Intraday precision was estimated by analyzing QC samples at three concentrations within $24 \mathrm{hrs}(\mathrm{n}=5)$. Inter-day precision was estimated by repeating analysis of QC samples over three consecutive days $(n=15)$. The variability in determination was expressed as the relative standard deviation (RSD, \%) and the accuracy was expressed as the relative error (RE, \%). The lower limit of quantification (LLOQ) was defined as the lowest concentration that could be determined with both RE and RSD within $20 \%$ (Lee et al., 2011).

\section{I- TA1718-B Quality Control}

The samples of ${ }^{125}$ - TA1718-B were separated and purified on Radio-iTLC paper, the samples were spread up in $85 \%$ methanol system and scanned by thin-layer chromatography (TLC) scanner. The samples of $\mathrm{Na}^{125}$ I solution were placed on Radio-iTLC paper and then spread up in $85 \%$ methanol system as control group. The retention factor (Rf) value was calculated by the formula as follows.

$\mathrm{Rf}=$ Retention Time (RT, $\mathrm{min})-0.15(\mathrm{~min}) / 0.78(\mathrm{~min})-0.15(\mathrm{~min})$.

$0.15 \mathrm{~min}$ is sampling origin, $0.78 \mathrm{~min}$ is the final solvent front. $\mathrm{RT}<0.15$ is defined that $\mathrm{Rf}$ is $0, \mathrm{RT}>0.78$ is defined that $R f$ is 1 . In this experiment, RT of ${ }^{125}$ I- TA1718-B should be among $0-0.1$, RT of Na ${ }^{125}$ I should be among 0.8-1.0.

\section{5/-TA1718-B Concentration and Specific activity assay}

The protein concentrations of ${ }^{125}$ I- TA1718-B solutions were detected by UV method and calculated according to the specific activity of ${ }^{125}$-TA1718-B solutions.

Specific Activity $(\mathrm{SA})=$ Radioactivity concentration $(\mathrm{mCi} / \mathrm{ml}) /$ Protein concentration $(\mathrm{mg} / \mathrm{ml})$.

\section{Statistical Analysis}

Linear log Trapezoidal method of WinNonlin Phoenix Soft (v6.4, Pharsight, Beijing, China) was used to calculated the pharmakinetic parameters such as $T_{1 / 2}, V_{d}, A U C, C L, C_{\max }, T_{\max }, M R T, A U C_{(0 \sim t)}$ and $\mathrm{AUC}_{(0 \sim \mathrm{inf})}$ in non compartment model manners. Data were calculated and analyzed with Excel 2010 (Microsoft, Redmond, WA, United States) and SPSS V19.0 (SPSS, Inc., Chicago, IL, United States). All values were presented as mean + SD, using an unpaired t-test by SPSS Statistics V19.0.

\section{Results}




\section{Precision and Accuracy}

The concentration, stability and homogeneity of the TA1718-B solutions were determined by UV-V is spectrophotometer (UV-6300 PC, MAPADA, Shanghai, China). For concentration of the upper, middle, and lower solutions determination was conducted in triplicate, respectively. The RSD (\%) between the measured concentrations and theoretical values should be from 90.77 to $95.32 \%$, and the RE (\%) were lower than $5 \%$. ELISA was used to detect the protein concentrations in cynomolgus monkeys' serum. After the standard curve fitting, the correlation coefficient of $R^{2}$ was above 0.99 .

\section{I-TA1718-B Quality Control}

125I-TA1718-B quality control assay demonstrated that the radiochemical purity (RCP) in 3 batches were $100 \%$, meet the standard (RCP $>90 \%$ ), and the specific activity (SA) were among 0.03-0.33. Radio-iTLC was used to verify the stability of ${ }^{125}$ I-TA1718-B. The results showed that either in 3.5 or $23 \mathrm{hrs}$, the RCP were $100 \%$, which meet the testing requirement.

\section{Cynomolgus monkeys' Plasma Pharmacokinetics Study}

To determine the PK characteristics, the plasma concentration-time profiles of TA1718-B were detected following single $(1,3$, and $10 \mathrm{mg} / \mathrm{kg})$ and repeat $(3 \mathrm{mg} / \mathrm{kg})$ i.v injection and the results were showed in Figure 1. The PK parameters were calculated and showed in Table 1 and Table 2. Compared the individual data in male and female monkeys, all PK parameters showed no significant differences in TA1718-B 1, $10 \mathrm{mg} / \mathrm{kg}$ single and $3 \mathrm{mg} / \mathrm{kg}$ repeat injected groups, only $\mathrm{C}_{\max }$ in TA1718-B-3 mg $/ \mathrm{kg}$ single injection group exhibited significant difference, but the ratio was above 1.5 , which indicated that there were no significant sexual differences (data was not shown) between male and female animals.

As results showed in Figure 1A, B and Table 1, after i.v injection with 1, 3, and $10 \mathrm{mg} / \mathrm{kg}$ TA1718-B, the $\mathrm{C}_{\mathrm{max}}$ in 3 groups were $27.0 \pm 2.50,64.4 \pm 13.5$, and $194 \pm 28.9 \mu \mathrm{g} / \mathrm{ml}$, respectively. The $A_{U} \mathrm{C}_{\text {INF_obs }}$ were $3920 \pm 533,8470 \pm 2380$, and $36900 \pm 16800 \mathrm{~h} * \mathrm{gg} / \mathrm{ml}$, respectively. AUC last were $3160 \pm 583,7000 \pm$ 1920 , and $36400 \pm 16300 \mathrm{~h} * \mathrm{gg} / \mathrm{ml}$, respectively. The proportions of $\mathrm{C}_{\max }, A_{U C_{\text {INF_obs, }}} A U C_{\text {last }}$ were $1: 2.39$ : $7.19,1: 2.16: 9.41$, and $1: 2.22: 11.5$, respectively. Meanwhile, the $\mathrm{Cl}_{\text {obs }}$ were $0.259 \pm 0.0385,0.386 \pm$ 0.139 , and $0.314 \pm 0.119 \mathrm{ml} / \mathrm{h} / \mathrm{kg}$, respectively. $T_{1 / 2 \_z}$ values were $136 \pm 49.6,113 \pm 75.5$, and $97.1 \pm 76.0$ hrs, respectively. MRT INF_obs $_{\text {were }} 201 \pm 62.7,193 \pm 74.2$, and $229 \pm 86.6 \mathrm{hrs}$, respectively. MRT last were $122 \pm 24.3,125 \pm 18.8$, and $217 \pm 70.6 \mathrm{hrs}$, respectively. $\mathrm{V}_{\text {ss_obs }}$ were $50.8 \pm 11.4,69.9 \pm 21.2$, and $64.0 \pm$ $10.2 \mathrm{ml} / \mathrm{kg}$, respectively.

In contrast, the first and last $C_{\max }$ of TA1718-B in serum when cynomolgus monkeys followed $3 \mathrm{mg} / \mathrm{kg}$ repeated injection were $83.6 \pm 16.0$ and $110 \pm 33.8 \mu \mathrm{g} / \mathrm{ml}$, respectively (Table 2). The ratio of $\mathrm{C}_{\text {max-first }}$ and 
$\mathrm{C}_{\text {max-last }}$ was $1: 1.32$. The valley concentrations after 4 consecutive injections were 0.00 ( $0 \mathrm{~h}$ before the first drug injection), $28.1,40.8$, and $31.1 \mu \mathrm{g} / \mathrm{ml}$, respectively, which indicated that 4 continuous injections did not resulted in drug accumulation. Within $168 \mathrm{hrs}$ after the first and last drug injection, the $\mathrm{AUC}_{(0-}$ $168 \mathrm{hrs}$ ) were $6610 \pm 1530$ and $6640 \pm 5860 \mathrm{~h} * \mathrm{\mu g} / \mathrm{ml}$, respectively. Additionally, the $\mathrm{Cl}_{\text {_obs }}$ were $0.205 \pm$ 0.0760 and $1.64 \pm 1.97 \mathrm{ml} / \mathrm{h} / \mathrm{kg}$, respectively. And the $T_{1 / 2 \_z}$ were $243 \pm 124$ and $84.6 \pm 117 \mathrm{hrs}$, respectively.

In additional, the fitting results of exposure parameters ( $\mathrm{C}_{\max }$ and $\left.\mathrm{AUC}\right)$ in 3-dosage groups were showed and the slope ( $\beta$-value) and $90 \%$ confidence interval $(\mathrm{Cl})$ were calculated. As showed in Table S1, the $\beta$ value and $90 \% \mathrm{Cl}$ of $C_{\max }$ were 0.856 and $0.787-0.926$, respectively, which excessed $0.8-1.25$, as well as

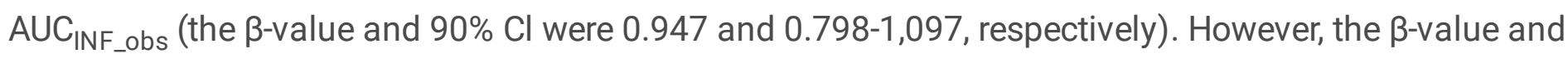
$90 \% \mathrm{Cl}$ of $\mathrm{AUC}_{\text {last }}$ were within the range ( $\beta$-value was $1.039,90 \% \mathrm{Cl}$ was $\left.0.887-1.191\right)$. All these results indicated that the increase of $A U C_{\text {last }}$ was proportional to the dosage increasement (from 1 to $10 \mathrm{mg} / \mathrm{kg}$ ), but not in $\mathrm{C}_{\max }$ and $\mathrm{AUC}_{\mathrm{INF} \_ \text {obs. }}$ There was no difference in dose groups and also no difference between male and female monkeys.

\section{Immunogenicity Assay}

To verify whether cynomolgus monkeys developed anti drug antibody (ADA) resulted from single/repeat TA1718-B injection, serum of animals at different time points after single (from 0 to $1008 \mathrm{hrs)} \mathrm{or} \mathrm{repeat}$ (from 0 to $1512 \mathrm{hrs)} \mathrm{drug} \mathrm{injection} \mathrm{were} \mathrm{collected} \mathrm{and} \mathrm{detected} \mathrm{by} \mathrm{ELISA.} \mathrm{As} \mathrm{results} \mathrm{showed} \mathrm{in} \mathrm{Figure}$ S1A, the ADA positive rates were 100\% (6/6), 100\% (6/6), and 66.7\% (4/6) when monkeys underwent 1,3 , and $10 \mathrm{mg} / \mathrm{kg}$ i.v injection, respectively. In additional, $3 \mathrm{mg} / \mathrm{kg}$ TA1718-B repeated injection resulted in 100\% (6/6) ADA positive rate (Figure S1B). There was no difference in dose groups and also no difference between male and female monkeys.

\section{MC38 Colon Cancer Humanized Mice Tissue Distribution Study}

To investigate the tissue distribution of TA1718-B, ${ }^{125}$ I labeled TA1718-B was used to i.v inject into MC38 colon cancer humanized mice. Tissues, plasma, and urine were collected at 2, 96, 168, and $240 \mathrm{hrs}$ after drug delivery, and the gamma counting results of different fractions after HPLC separation were detected and calculated.

The HPLC showed that the retention time of ${ }^{125} \mathrm{I}-\mathrm{TA} 1718$-B was 10.7 min (Figure S2A). At 2, and 96 hrs after i.v injection, prototype drug could be detected but not at 168 and $240 \mathrm{hrs}$ in plasma (Figure S2B-E). In contrast, prototype ${ }^{125}$ I-TA1718-B were not detected in urine during the whole experiment (Figure S2F-I), which indicated that metabolites of ${ }^{125}$ I-TA1718-B were not mainly by urine but by proteolytic 
degradation. Meanwhile, in order to avoid the influence of thyroid on drug distribution, the drug total radioactivity in thyroid were $0.09 \pm 0.02 \%$ ( $2 \mathrm{hrs}$ ), $0.05 \pm 0.01 \%$ (96 hrs), $0.05 \pm 0.01 \%$ (168 hrs), and 0.06 $\pm 0.03 \%(240 \mathrm{hrs})$, respectively, which indicated that the reliability of tissue distributions of ${ }^{125} \mathrm{I}-\mathrm{TA} 1718-\mathrm{B}$ was not interfered by thyroid (Table S2).

To verify the trichloroacetic acid (TCA) precipitation method, all mice tissues/body fluid and vehicle were added ${ }^{125}$ I-TA1718-B in a series of concentrations ( $3 \mu \mathrm{g}, 0.3 \mu \mathrm{g}, 30 \mathrm{ng}, 15 \mathrm{ng}$, and $3 \mathrm{ng}$ ), total and precipitated radioactivity were calculated and the result was showed in Table S3 and Figure S3. All results demonstrated that there were linear correlations between the total radioactivity and precipitated radio activity. The correlation coefficients were above 0.999 , and the acid precipitation rates were more than $94 \%$.

The tissue distributions of ${ }^{125}$ I-TA1718-B in mice were performed and showed in Figure 2 and Table S2. The data suggested that the ${ }^{125}$-TA1718-B was widely distributed throughout all tissues and even the brain, testis (or uterus) and bone (Figure 2A). At 2 hrs after ${ }^{125}$ I-TA1718-B injection, the drug concentrations in ovary and lung were peaked (14.00 \pm 1.91 and $12.14 \pm 2.45 \mu \mathrm{gEqu} / \mathrm{g}$, respectively); the kidney, tumor, mesenteric nodes, spleen, heart, liver, bone, intestine, testis, and stomach contained moderate amounts of ${ }^{125}$ I-TA1718-B (from 2.44 to $8.40 \mu \mathrm{gEqu} / \mathrm{g}$ ); and tissue extracts from fat, brain, and muscle contained low concentrations (below $2.00 \mu \mathrm{gEqu} / \mathrm{g}$ ). At $96 \mathrm{hrs}$ after ${ }^{125} \mathrm{I}-\mathrm{TA} 1718-\mathrm{B}$ administration, tissue extracts from tumor, mesenteric nodes, and lung still had comparatively high concentrations of 125 -TA1718-B (4.47 $\pm 1.58,4.09 \pm 1.09$, and $3.56 \pm 0.84 \mu \mathrm{gEqu} / \mathrm{g}$, respectively). In additional, at $240 \mathrm{hrs}$

after administration, ${ }^{125}$-TA1718-B was undetected in ovary, liver, fat, brain, and muscle, and other tissues (Figure 2B). The AUC from 0 to 240 hrs in different tissues after drug injection was plasma $>$ ovary $>$ lung $>$ tumor $>$ mesenteric nodes $>$ kidney $>$ spleen $>$ liver $>$ heart $>$ fat $>$ stomach $>$ bone $>$ intestine $>$ testis $>$ muscle $>$ brain (Figure 3). In addition to lung, ovary and serum, tumors had the highest exposure to radio pharmaceutical compared with other tissues, indicating that tumors had specific uptake of ${ }^{125}$ I-TA1718-B. There was no difference in different groups.

\section{The Excretion of ${ }^{125}$ I-TA1718-B in Rats}

To detect the excretion characteristics of ${ }^{125}$-TA1718-B, BDC and SD rats were i.v injected with ${ }^{125}$ ITA1718-B. Urine, feces and bile (BDC rats) were collected at different time points and detected by HPLC and $y$-ray counter. As results showed in Figure $4 \mathrm{~A}$ and Table 3 , the accumulated excretion ratios of ${ }^{125}$ TA1718-B from $0 \mathrm{~h}$ to $4,8,24$, and $48 \mathrm{hrs}$ in BDC rats' bile were $0.2 \pm 0.1 \%, 0.4 \pm 0.1 \%, 1.6 \pm 0.4 \%$, and 3.9 $\pm 0.9 \%$, respectively. After drug injection, the accumulative excretion rates (from 0 to $840 \mathrm{hrs}$ ) in urine, feces, and total (urine plus feces) were $69.2 \% \pm 5.9 \%, 17.2 \% \pm 11.7 \%$, and $86.4 \% \pm 9.3 \%$, respectively (Table 4 and Figure 4B). However, no radioactivity peak was observed in urine samples at the 
corresponding time of the prototype drug, which indicated that the radiopharmaceuticals in urine mainly existed in the form of proteolytic degradation.

\section{Discussion}

A large number of companies in China currently are in developing or clinical stage of PD-1. The recombinant humanized anti-PD-1 monoclonal antibody (TA1718-B) is developed by Lunan Pharmaceutical Group Co. Ltd. and is entering clinical Phase I trials. In this study, the systematical pharmacokinetic studies including plasma kinetics, tissue distributions, and excretions of TA1718-B were performed in cynomolgus monkeys, MC38 colon cancer humanized mice, and SD rats, respectively.

Early PK liabilities of mAb drugs were often usually identified using rodent models. Pilot PK/PD and safety studies are in appropriate species (NHP and rodent) [18]. So we evaluated the PK of TA1718-B using rats, mice and monkeys.

The cynomolgus monkeys were underwent single $(1,3$, and $10 \mathrm{mg} / \mathrm{kg}$ ) or repeat (4 times, $3 \mathrm{mg} / \mathrm{kg}$ ) intravenous injection with 1,3 , and $10 \mathrm{mg} / \mathrm{kg}$ TA1718-B. The PK parameters showed that 1,3 , and 10 $\mathrm{mg} / \mathrm{kg}$ single injection did not result in significantly differences between male and female monkeys. And from 1 to $10 \mathrm{mg} / \mathrm{kg}$ drug delivery dose, the increase of $\mathrm{AUCl}_{\text {ast }}$ was proportional to the dosage increasement (The $A U C_{\text {last }}$ were $3160 \pm 583,7000 \pm 1920$, and $36400 \pm 16300 \mathrm{~h} * \mu \mathrm{g} / \mathrm{ml}$, respectively. The AUC $_{\text {last }}$ and dosage ratios were $1: 2.2: 11.5$ and $1: 3: 10$, respectively.). However, the $C_{\max }$ increases were indirectly correlated with the dosage (The $C_{\max }$ were $27 \pm 2.5,64.4 \pm 13.5$, and $194 \pm 28.9 \mu \mathrm{g} / \mathrm{ml}$, respectively. The ratio was $1: 2.38: 7.18)$, and the growth rates were slower than the increase of dose. In additional, $\mathrm{C}_{\max }$ ratio between the first and the last drug exposure after 4-times continuous injection ( 3 $\mathrm{mg} / \mathrm{kg}$ ) was 1.32-fold (the $C_{\text {max-first }}$ and $C_{\text {max-last }}$ were $83.6 \pm 16.0$ and $110 \pm 33.8 \mu \mathrm{g} / \mathrm{ml}$, respectively). The ratio of $\mathrm{AUC}_{(0-168 \mathrm{hrs})}$ was 1.0-fold $\left(\mathrm{AUC}_{(0-168 \mathrm{hrs}) \text {-first }}\right.$ and $\mathrm{AUC}_{(0-168 \mathrm{hrs})}$-last were $6610 \pm 1530$ and $6640 \pm$ $5860 \mathrm{~h}^{\star} \mu \mathrm{g} / \mathrm{ml}$, respectively). In additional, the $C_{\text {through }}$ before each injection were $0.00,28.1,40.8$, and $31.1 \mu \mathrm{g} / \mathrm{ml}$. All these results demonstrated that 4-times continuous TA1718-B i.v injection could not result insignificant drug accumulation. $3 \mathrm{mg}$ dose was used for repeat administration due to previous pharmacodynamics study we also referred to the clinical doses of Nivolumab and Keytruda $(2-3 \mathrm{mg} / \mathrm{kg})$ [19]. It is a dose determined to use for human body.

With the clinical applications of more and more protein medicines to address unmet medical needs such as cancer, autoimmune disease and other diseases, their safety and efficacy should be ensured (FDA, 2014). As with all therapeutic proteins, there is a potential for immunogenicity. The emergence of ADA (anti-drug antibodies) can potentially lead to loss of efficacy and/or adverse effects because of protein medicines' structure containing potential B- and T-cell epitopes, which resulted in the production of T-cell epitope peptides [20]. Therefore, evaluating the potential immunogenicity risk should be considered during the development of therapeutic protein products [21]. The immunogenicity of TA1718-B single or repeat injected in cynomolgus monkeys were detected by ELISA. The positive rates of ADA after 1, 3, and $10 \mathrm{mg} / \mathrm{kg}$ single administration were 100\% (6/6), 100\% (6/6), and 66.7\% (4/6). In contrast, $3 \mathrm{mg} / \mathrm{kg}$ 
TA1718-B repeat injection resulted in 100\% (6/6) of ADA positive rate. These results suggested that the ADA may neutralized the activity of TA1718-B and influenced drug's elimination, plasma $T_{1 / 2}$, tissue distributions, and even PD/PK features. To cynomolgus monkeys, this recombined mAb is a heterologous protein, so ADA rate is high. And only part of the ADA induced by PD-1 mAb is neutralizing antibody. And it is reported that, in most cases, ADA occurs mainly in animals exposed to lower doses rather than higher doses. This may be associated with high dose induced tolerance (high zone tolerance) [22]. Immunogenicity or ADA response found in preclinical species does not predict ADA response in human. Keytruda is a good example that is quite immunogenic in cynomolgus monkeys with a high incidence of ADA but only with low ADA incidence (1.7\%) (http://www.accessdata.fda.gov/drugsatfda_docs/nda/2014/1255140rig1s000PharmR.pdf)). So here we speculate the incidence of ADA and neutralizing antibody may be low in human.

Once a drug enters into systemic circulation by absorption or direct administration, it must be distributed into different organs or tissues [23] and its metabolites need to be removed from the body via excretion through the kidneys (urine) or the feces [24]. Although there are differences between small molecules and monoclonal antibodies, mAbs also can arrive at different tissues by convection. And in general, antibody concentrations in tissue interstitial fluid are substantially lower than antibody concentrations in plasma because of the differences in the rate of convective uptake (which is slow) and elimination of antibody from tissue (which could be fast) [22]. Otherwise, antibodies are mainly eliminated by excretion or catabolism. Although mAb is too large to be eliminated by urine excretion, but proteolytic fragments can be filtered by kidney when mAb is catabolic in vivo. TCA precipitability indicated that all of the radioactivity in urine was represented by proteolyzed/degraded $\mathrm{mAb}$. The distributive and excretory capacity of a drug is strongly associated with its efficacy and/or adverse events [25]. In this study, tissue distributions of TA1718-B were detected in MC38 colon cancer humanized mice by i.v injection with3 $\mathrm{mg} / \mathrm{kg}^{125} \mathrm{I}$-TA1718-B. MC38 colon cancer humanized mice is a general model to evaluate biodistribution or intratumoral distribution of PD1/PDL1 mAb [26]. All tissues were collected from 2 hrs to $240 \mathrm{hrs}$ after drug delivery and the total radioactivity of ${ }^{125}$-TA1718-B were detected. Results demonstrated that the AUC from 0 to 240 hrs in different tissues after drug injection were plasma $>$ ovary $>$ lung $>$ tumor $>$ mesenteric nodes $>$ kidney $>$ spleen $>$ liver $>$ heart $>$ fat $>$ stomach $>$ bone $>$ intestine $>$ testis $>$ muscle $>$ brain. In addition to serum, ovaries and lungs, tumors had the highest exposure to radiopharmaceuticals compared with other tissues, indicating that tumors had specific uptake of ${ }^{125}$ I-TA1718-B.The mAB tissue distribution is affected by various factors such as isoelectric point ( $\mathrm{PI})$, protein size and affinity to target of mAb [27]. Although antibodies developed against an antigen are highly specific to that antigen, some mAbs can have multi-specificity binding capability for irrelevant antigens. It is reported that small proteins could be eliminated rapidly by kidney filtration and a better affinity could improve tumor accumulation. But impact of large mAb protein on tumor accumulation is dismissed [22]. Our data could not exhibit that the antibody is nonspecific.

Our results displayed that TA1718-B concentration in tumor tissue is lower than that in ovary, lung, kidney, liver and so on. There is a theory "binding site barrier" to explain it, which means a mAb with a moderate 
affinity was associated with the highest tumor accumulation, however, mAb with high affinity produces low tumor accumulation[28, 29]. And TA1718-B is a PD-1 mAb with a high affinity, so it exhibited a low accumulation in tumor tissue.

Subsequently, we investigated the urine, feces and bile excretions of TA1718-B in SD or BDC rats after i.v of ${ }^{125} \mathrm{I}-\mathrm{TA} 1718-\mathrm{B}(3 \mathrm{mg} / \mathrm{kg})$. Within $840 \mathrm{hrs}$ after drug delivery, the urine accumulative excretion ratio was $69.2 \% \pm 5.9 \%$, and the ratio reached a platform after $336 \mathrm{hrs}$, probably resulting from its high lipophilic and plasma protein binding capacity. Discharge from bile into intestines and intestinal autocrine are the predominant mechanisms when drugs excrete via feces. In this experiment, TA1718-B was not detected in the feces within $96 \mathrm{hrs}$ after ${ }^{125}$-TA1718-B administration, and the excretory amount of TA1718-B in feces (0-840 hrs) and bile (0-48 hrs) were $17.2 \% \pm 11.7 \%$ and $3.9 \% \pm 0.9 \%$, respectively. The urine accumulative excretion ratio is high, suggesting that radiopharmaceutical TA1718-B in urine mainly existed in the form of proteolytic degradation.

\section{Conclusions}

In this research, the systemetic pharmacokinetic studies of recombinant humanized anti PD-1 monoclonal antibody (TA1718-B) were performed in cynomolgus monkeys, MC38 colon cancer humanized mice, and rats. TA1718-B exhibited long $T_{1 / 2}$ (from 97 to $136 \mathrm{hrs}$ ) and low $\mathrm{Cl}$ (from 0.25 to $0.38 \mathrm{ml} / \mathrm{h} / \mathrm{kg}$ ) after intravenous single injection. 4-time continuous injection did not result in significantly drug accumulation. Both drug delivery ways resulted in high ADA positive rates. Meanwhile, after injection, the tissue distributions of TA1718-B were widely (almost all tissues) including tumor tissue. All these data are worthy for further exploration.

\section{Abbreviations}

$\mathrm{C}_{\max }$, Maximum observed concentration. $\mathrm{T}_{\text {max }}$, Time of maximum observed concentration. $\mathrm{AUC}_{\text {last }}$, Area under the curve from the time of dosing (dosing time) to the last measurable (positive) concentration. $\mathrm{AUC}_{\mathrm{INF}_{\mathrm{NObS}} \text {, }} \mathrm{AUC}$ from dosing time extrapolated to infinity, based on the last observed concentration. $\mathrm{T}_{1 / 2 \_z}$, Apparent terminal phase half-life. $\mathrm{Cl}_{\text {_obs }}$ or $\mathrm{Cl}_{\text {_F_obs, }}$ Total body clearance for extravascular administration. MRT INF_obs, $_{\text {Mean residence time (MRT) extrapolated to infinity. MRT last, }}$ Mean residence time from the time of dosing (dosing time) to the time of the last measurable concentration. $\mathrm{V}_{\mathrm{z}_{-} \mathrm{obs}}$ or

$V_{Z_{Z} F_{-} o b s}$, Volume of distribution based on the terminal phase. $V_{S S_{-} \text {obs, }}$ An estimate of the volume of distribution at steady state. BQL, Below quantitation limit. CV\%, Coefficient of variation. ADA, anti-drug antibody

\section{Declarations}

\section{Ethics approval and consent to participate}


All animal experiments were complied with the ARRIVE guidelines and carried out in accordance with the National Institutes of Health guide for the care and use of Laboratory animals. All the animal including rats, mice and monkeys experiments were approved by the Institutional Animal Care and Use Committees (IACUC) of MITRO Biotech Co. Ltd., Shanghai InnoStar Bio-Tech Co. Ltd. in the contracts, respectively, and followed the "3Rs" rule (Reduction, Refinement, and Replacement).

\section{Consent for publication}

Not applicable.

\section{Availability of data and materials}

The datasets used and/or analyzed during the current study are available from the corresponding author on reasonable request.

\section{Competing interest}

The authors declare that they have no competing interests.

\section{Funding}

This work was supported by the grants from the Shandong Province Open Innovation Fund For Collaborative Innovation Of Antibody And Pharmacy Project [grant no. CIC-AD1806] gratefully received from the National Engineering and Technology Research Center of Chirality Pharmaceutical and Lunan Pharmaceutical Group Co. Ltd.. And the funder had the following involvement with designing the structure of TA1718-B and drafting pharmacokinetic experiment programme.

\section{Author contributions}

LLZ and JL contributed to the conception and design of the study. JL and YSR contributed to the data analysis, drafting article and approved the final version to be submitted. YGL, ZTL, and DM performed sample collection from experimental animals. LFL, GMZ performed sample detection. All authors read and approved the final manuscript for submission. 
Acknowledgements

Not applicable.

\section{References}

1. Brahmer JR, Drake CG, Wollner I, Powderly JD, Picus J, Sharfman WH, Stankevich E, Pons A, Salay TM, McMiller TL et al: Phase I study of single-agent anti-programmed death-1 (MDX-1106) in refractory solid tumors: safety, clinical activity, pharmacodynamics, and immunologic correlates. Journal of clinical oncology : official journal of the American Society of Clinical Oncology 2010, 28(19):3167-3175.

2. Merelli B, Massi D, Cattaneo L, Mandala M: Targeting the PD1/PD-L1 axis in melanoma: biological rationale, clinical challenges and opportunities. Critical reviews in oncology/hematology 2014, 89(1):140-165.

3. Miller TJ, McCoy MJ, Hemmings C, lacopetta B, Platell CF: Expression of PD-L1 and SOX2 during rectal tumourigenesis: Potential mechanisms for immune escape and tumour cell invasion. Oncology letters 2018, 16(5):5761-5768.

4. Cerezo D, Pena MJ, Mijares M, Martinez G, Blanca I, De Sanctis JB: Peptide vaccines for cancer therapy. Recent patents on inflammation \& allergy drug discovery 2015, 9(1):38-45.

5. Whiteside TL: Head and Neck Carcinoma Immunotherapy: Facts and Hopes. Clinical cancer research : an official journal of the American Association for Cancer Research 2018, 24(1):6-13.

6. Shum T, Kruse RL, Rooney CM: Strategies for enhancing adoptive T-cell immunotherapy against solid tumors using engineered cytokine signaling and other modalities. Expert opinion on biological therapy 2018, 18(6):653-664.

7. Ribas A, Dummer R, Puzanov I, VanderWalde A, Andtbacka RHI, Michielin O, Olszanski AJ, Malvehy J, Cebon J, Fernandez E et al: Oncolytic Virotherapy Promotes Intratumoral T Cell Infiltration and Improves Anti-PD-1 Immunotherapy. Cel/2017, 170(6):1109-1119 e1110.

8. Yousefi H, Yuan J, Keshavarz-Fathi M, Murphy JF, Rezaei N: Immunotherapy of cancers comes of age. Expert review of clinical immunology 2017, 13(10):1001-1015.

9. Xing Y, Hogquist KA: T-cell tolerance: central and peripheral. Cold Spring Harbor perspectives in biology $2012,4(6)$.

10. Wilson MK, Karakasis K, Oza AM: Outcomes and endpoints in trials of cancer treatment: the past, present, and future. The Lancet Oncology 2015, 16(1):e32-42.

11. Goubet AG, Livartowski A, Romano E: [Immunotherapy in lung cancer: New concepts]. Revue des maladies respiratoires 2018, 35(6):642-651.

12. Pardoll DM: The blockade of immune checkpoints in cancer immunotherapy. Nature reviews Cancer 2012, 12(4):252-264. 
13. Weber JS, D'Angelo SP, Minor D, Hodi FS, Gutzmer R, Neyns B, Hoeller C, Khushalani NI, Miller WH, Jr., Lao CD et al: Nivolumab versus chemotherapy in patients with advanced melanoma who progressed after anti-CTLA-4 treatment (CheckMate 037): a randomised, controlled, open-label, phase 3 trial. The Lancet Oncology 2015, 16(4):375-384.

14. Rodig SJ, Gusenleitner D, Jackson DG, Gjini E, Giobbie-Hurder A, Jin C, Chang H, Lovitch SB, Horak C, Weber JS et al: MHC proteins confer differential sensitivity to CTLA-4 and PD-1 blockade in untreated metastatic melanoma. Science translational medicine 2018, 10(450).

15. Botti G, Collina F, Scognamiglio G, Rao F, Peluso V, De Cecio R, Piezzo M, Landi G, De Laurentiis M, Cantile M et al: Programmed Death Ligand 1 (PD-L1) Tumor Expression Is Associated with a Better Prognosis and Diabetic Disease in Triple Negative Breast Cancer Patients. International journal of molecular sciences 2017, 18(2).

16. Wait SD, Prabhu RS, Burri SH, Atkins TG, Asher AL: Polymeric drug delivery for the treatment of glioblastoma. Neuro-oncology 2015, 17 Suppl 2:ii9-ii23.

17. Zhang T, Song X, Xu L, Ma J, Zhang Y, Gong W, Zhou X, Wang Z, Wang Y, Shi Y et al: The binding of an anti-PD-1 antibody to FcgammaRlota has a profound impact on its biological functions. Cancer immunology, immunotherapy : CII 2018, 67(7):1079-1090.

18. Ovacik M, Lin K: Tutorial on Monoclonal Antibody Pharmacokinetics and Its Considerations in Early Development. Clinical and translational science 2018, 11(6):540-552.

19. Fessas P, Lee H, Ikemizu S, Janowitz T: A molecular and preclinical comparison of the PD-1-targeted T-cell checkpoint inhibitors nivolumab and pembrolizumab. Seminars in oncology 2017, 44(2):136140.

20. Fernandez L, Bustos RH, Zapata C, Garcia J, Jauregui E, Ashraf GM: Immunogenicity in Protein and Peptide Based-Therapeutics: An Overview. Current protein \& peptide science 2018, 19(10):958-971.

21. Rosenberg AS, Sauna ZE: Immunogenicity assessment during the development of protein therapeutics. The Journal of pharmacy and pharmacology 2018, 70(5):584-594.

22. Liu L: Pharmacokinetics of monoclonal antibodies and Fc-fusion proteins. Protein \& cel/ 2018, 9(1):15-32.

23. Yadav P, McLeod VM, Nowell CJ, Selby LI, Johnston APR, Kaminskas LM, Trevaskis NL: Distribution of therapeutic proteins into thoracic lymph after intravenous administration is protein size-dependent and primarily occurs within the liver and mesentery. Journal of controlled release : official journal of the Controlled Release Society 2018, 272:17-28.

24. Choi HS, Liu W, Misra P, Tanaka E, Zimmer JP, Itty Ipe B, Bawendi MG, Frangioni JV: Renal clearance of quantum dots. Nature biotechnology 2007, 25(10):1165-1170.

25. Cohen JA, Chun J: Mechanisms of fingolimod's efficacy and adverse effects in multiple sclerosis. Annals of neurology 2011, 69(5):759-777.

26. Deng R, Bumbaca D, Pastuskovas CV, Boswell CA, West D, Cowan KJ, Chiu H, McBride J, Johnson C, Xin $Y$ et al: Preclinical pharmacokinetics, pharmacodynamics, tissue distribution, and tumor 
penetration of anti-PD-L1 monoclonal antibody, an immune checkpoint inhibitor. mAbs 2016, 8(3):593-603.

27. James LC, Roversi P, Tawfik DS: Antibody multispecificity mediated by conformational diversity. Science 2003, 299(5611):1362-1367.

28. Fujimori K, Covell DG, Fletcher JE, Weinstein JN: A modeling analysis of monoclonal antibody percolation through tumors: a binding-site barrier. Journal of nuclear medicine : official publication, Society of Nuclear Medicine 1990, 31(7):1191-1198.

29. Rudnick SI, Lou J, Shaller CC, Tang Y, Klein-Szanto AJ, Weiner LM, Marks JD, Adams GP: Influence of affinity and antigen internalization on the uptake and penetration of Anti-HER2 antibodies in solid tumors. Cancer research 2011, 71(6):2250-2259.

\section{Tables}

Table 1 Pharmacokinetic parameters ofTA1718-B after intravenous single administrations in cynomolgus monkeys

\begin{tabular}{|c|c|c|c|c|c|c|c|c|c|c|}
\hline \multirow[t]{2}{*}{ Parameter } & \multirow[t]{2}{*}{ Unit } & \multicolumn{3}{|c|}{ TA1718-B-1 mg/kg } & \multicolumn{3}{|c|}{ TA1718-B-3 mg/kg } & \multicolumn{3}{|c|}{ TA1718-B-10 mg/kg } \\
\hline & & Mean & SD & CV \% & Mean & SD & CV \% & Mean & SD & CV \% \\
\hline $\mathrm{AUC}_{\text {INF_obs }}$ & $\mathrm{h}^{*} \mu \mathrm{g} / \mathrm{ml}$ & 3920 & 533 & 13.6 & 8470 & 2380 & 28 & 36900 & 16800 & 45.5 \\
\hline $\mathrm{AUC}_{\text {last }}$ & $\mathrm{h}^{*} \mu \mathrm{g} / \mathrm{ml}$ & 3160 & 583 & 18.4 & 7000 & 1920 & 27.4 & 36400 & 16300 & 44.9 \\
\hline $\mathrm{Cl}_{-} \mathrm{obs}$ & $\mathrm{ml} / \mathrm{h} / \mathrm{kg}$ & 0.259 & 0.0385 & 14.8 & 0.386 & 0.139 & 36.1 & 0.314 & 0.119 & 38 \\
\hline $\mathrm{C}_{\max }$ & $\mu \mathrm{g} / \mathrm{ml}$ & 27 & 2.5 & 9.26 & 64.4 & 13.5 & 21 & 194 & 28.9 & 14.9 \\
\hline $\mathrm{MRT}_{\mathrm{INF} \_\mathrm{obs}}$ & $\mathrm{h}$ & 201 & 62.7 & 31.1 & 193 & 74.2 & 38.5 & 229 & 86.6 & 37.9 \\
\hline $\mathrm{MRT}_{\text {last }}$ & $\mathrm{h}$ & 122 & 24.3 & 19.9 & 125 & 18.8 & 15 & 217 & 70.6 & 32.5 \\
\hline $\mathrm{T}_{1 / 2 \_\mathrm{z}}$ & $\mathrm{h}$ & 136 & 49.6 & 36.4 & 113 & 75.5 & 67 & 97.1 & 76 & 78.3 \\
\hline $\mathrm{T}_{\max }$ & $\mathrm{h}$ & 0.5 & 0.5 & 2 & 0.5 & 0.5 & 0.5 & 0.5 & 0.5 & 2 \\
\hline $\mathrm{V}_{\text {ss_obs }}$ & $\mathrm{ml} / \mathrm{kg}$ & 50.8 & 11.4 & 22.4 & 69.9 & 21.2 & 30.3 & 64 & 10.2 & 15.9 \\
\hline $\mathrm{V}_{\mathrm{z}_{-} \mathrm{obs}}$ & $\mathrm{ml} / \mathrm{kg}$ & 49.3 & 13.6 & 27.5 & 59.8 & 35.7 & 59.7 & 36.4 & 18.6 & 51.2 \\
\hline
\end{tabular}

$\mathrm{n}=6$ per treatment group, results were presented as Mean \pm SD. 
Table2 Pharmacokinetic parameters of TA1718-B after intravenous repeated administrations in cynomolgus monkeys

\begin{tabular}{|c|c|c|c|c|c|c|c|}
\hline \multirow[t]{3}{*}{ Parameter } & \multirow[t]{3}{*}{ Units } & \multicolumn{6}{|c|}{ TA1718-B-3 mg/kg (i.v) } \\
\hline & & \multicolumn{3}{|c|}{ FDD } & \multicolumn{3}{|c|}{ LDD } \\
\hline & & Mean & SD & CV\% & Mean & SD & CV\% \\
\hline $\mathrm{AUC}_{0 \_168}$ & $\mathrm{~h}^{*} \mu \mathrm{g} / \mathrm{ml}$ & 6610 & 1530 & 23.1 & 6640 & 5860 & 88.4 \\
\hline $\mathrm{AUC}_{\mathrm{INF} \text { _obs }}$ & $\mathrm{h}^{*} \mu \mathrm{g} / \mathrm{ml}$ & 16600 & 6860 & 41.3 & 12300 & 12600 & 102 \\
\hline $\mathrm{AUC}_{\text {last }}$ & $\mathrm{h}^{*} \mu \mathrm{g} / \mathrm{ml}$ & 6610 & 1530 & 23.1 & 12200 & 12400 & 102 \\
\hline $\mathrm{Cl}_{-} \mathrm{obs}$ & $\mathrm{ml} / \mathrm{h} / \mathrm{kg}$ & 0.205 & 0.076 & 37 & 1.64 & 1.97 & 120 \\
\hline $\mathrm{C}_{\max }$ & $\mu \mathrm{g} / \mathrm{ml}$ & 83.6 & 16 & 19.1 & 110 & 33.8 & 30.7 \\
\hline $\mathrm{MRT}_{\mathrm{INF} \text { _obs }}$ & $\mathrm{h}$ & 344 & 176 & 51 & 115 & 110 & 95.4 \\
\hline $\mathrm{MRT}_{\text {last }}$ & $\mathrm{h}$ & 71.8 & 3.15 & 4.38 & 109 & 101 & 93 \\
\hline $\mathrm{T}_{1 / 2 \_\mathrm{z}}$ & $\mathrm{h}$ & 243 & 124 & 51.2 & 84.6 & 117 & 139 \\
\hline $\mathrm{T}_{\max } *$ & $\mathrm{~h}$ & 0.5 & 0.5 & 2 & 0.5 & 0.5 & 2 \\
\hline $\mathrm{V}_{\text {ss_obs }}$ & $\mathrm{ml} / \mathrm{kg}$ & 63.4 & 24.5 & 38.6 & 42.4 & 19.6 & 46.3 \\
\hline $\mathrm{V}_{\mathrm{z}_{-} \mathrm{obs}}$ & $\mathrm{ml} / \mathrm{kg}$ & 64.8 & 26.5 & 40.8 & 49.7 & 33.4 & 67.1 \\
\hline
\end{tabular}

FDD, first drug delivery; LDD, last drug delivery. $\mathrm{n}=6$ per treatment group, results were presented as Mean $\pm \mathrm{SD}$.

Table3 The individual cumulative excretion in bile of BDC rats after i.v injection with ${ }^{125}$ I-TA1718-B. 


\begin{tabular}{ccccc}
\hline Time (hrs) & $\mathbf{0 - 4}$ & $\mathbf{0 - 8}$ & $\mathbf{0 - 2 4}$ & $\mathbf{0 - 4 8}$ \\
\hline G2-F-01 & 0.3 & 0.5 & 2.0 & 4.3 \\
G2-F-02 a & 0.3 & 0.5 & 1.5 & 3.6 \\
\hline G2-F-03 & 0.1 & 0.4 & 2.0 & 5.3 \\
\hline G2-M-01 & 0.2 & 0.4 & 1.3 & 3.7 \\
\hline G2-M-02 & 0.3 & 0.5 & 1.7 & 3.7 \\
\hline G2-M-03 & 0.1 & 0.2 & 1.1 & 2.6 \\
\hline Mean & 0.2 & 0.4 & 1.6 & 3.9 \\
\hline SD & 0.1 & 0.1 & 0.4 & 0.9 \\
\hline
\end{tabular}

Table4 Cumulative excretion in feces and urine of SD rats after i.v injection with ${ }^{125}$ I-TA1718-B.

\begin{tabular}{ccccccc}
\hline \multirow{2}{*}{ Time } & \multicolumn{3}{c}{ Cumulative Excretion (\% of total injected radioactivity, Mean \pm SD) } \\
(hrs) & Urine & \multicolumn{2}{c}{ Feces } & \multicolumn{2}{c}{ Feces + Urine } \\
\hline $0-8$ & 1.9 & 0.4 & 0 & 0 & 1.9 & 0.4 \\
$0-24$ & 10 & 2.3 & 0.2 & 0.2 & 10.2 & 2.4 \\
\hline $0-48$ & 21.1 & 4.2 & 0.9 & 0.4 & 21.9 & 4.5 \\
\hline $0-96$ & 31.8 & 5.9 & 2.7 & 0.5 & 34.5 & 5.9 \\
\hline $0-168$ & 45.5 & 6.3 & 10.1 & 11.9 & 55.6 & 9.6 \\
\hline $0-336$ & 60.7 & 6 & 14.7 & 11.7 & 75.4 & 9.7 \\
\hline $0-504$ & 66.1 & 6.1 & 16.37 & 11.7 & 82.4 & 9.4 \\
\hline $0-672$ & 68.3 & 5.9 & 17.2 & 11.7 & 85.5 & 9.3 \\
\hline $0-840$ & 69.2 & 5.9 & 17.2 & 11.7 & 86.4 & 9.3 \\
\hline
\end{tabular}

Figures 
Figure 1

A

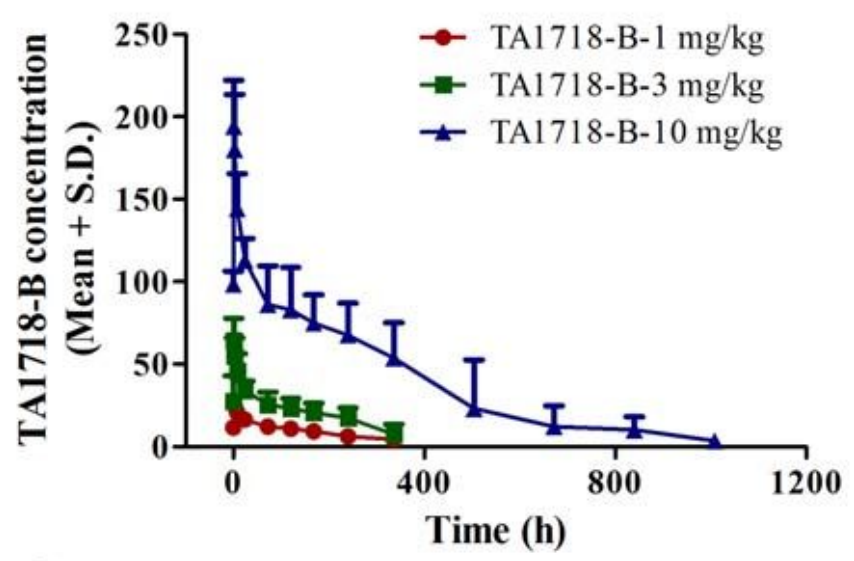

C

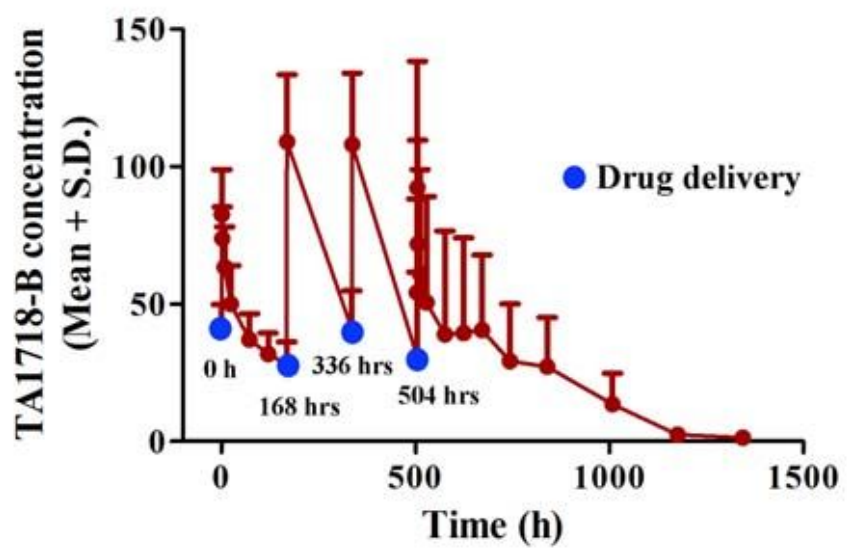

B

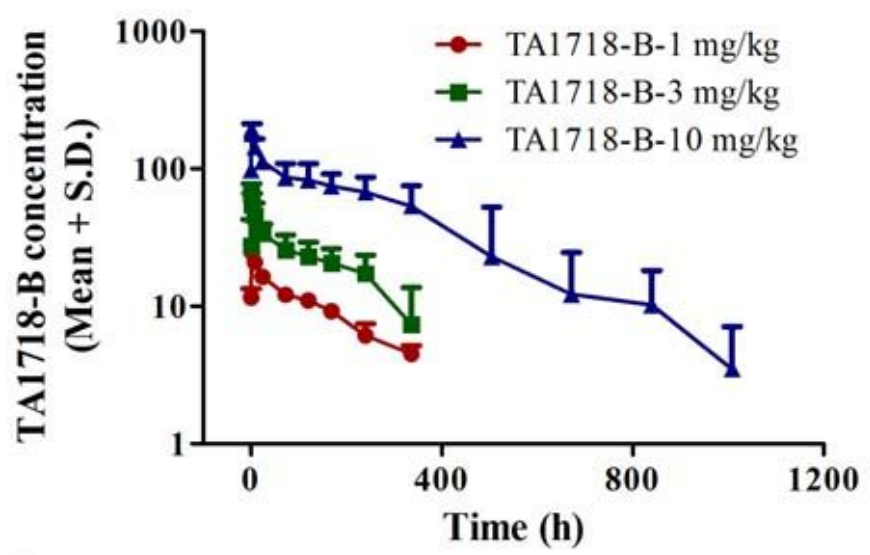

D

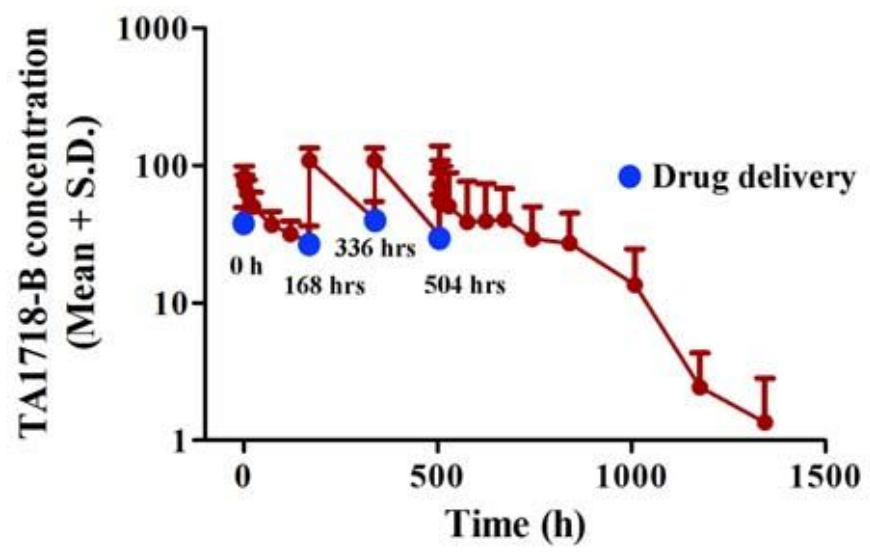

Figure 1

The plasma concentration of TA1718-B in cynomolgus monkeys after single or repeat intravenous injection (i.v). (A, B) Different TA1718-B concentrations of cynomolgus monkeys' plasma after single i.v with 1,3 or $10 \mathrm{mg} / \mathrm{kg}$. (C, D) Different TA1718-B concentrations of cynomolgus monkeys' plasma after repeat i.v with $3 \mathrm{mg} / \mathrm{kg}$. The results showed as normal (left) or semilogarithmic coordinates (right). ( $\mathrm{n}=6$ per treatment group; results are presented as the mean $\pm \mathrm{SD}$ ). 
Figure 2

A

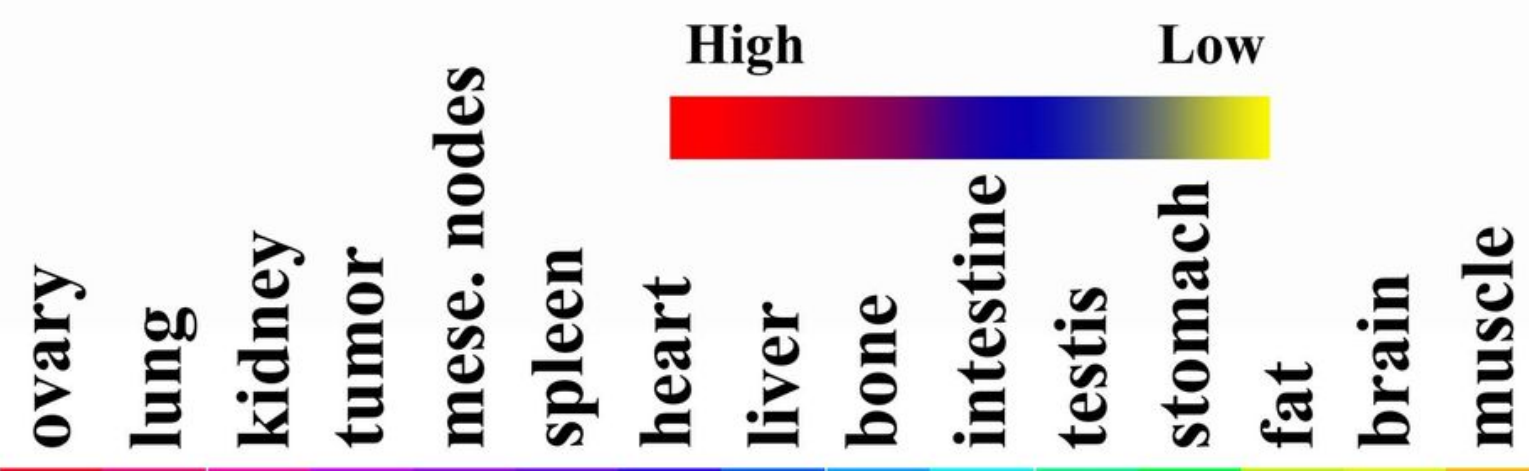

\section{2 hrs \\ 96 hrs \\ 168 hrs \\ 240 hrs}

B
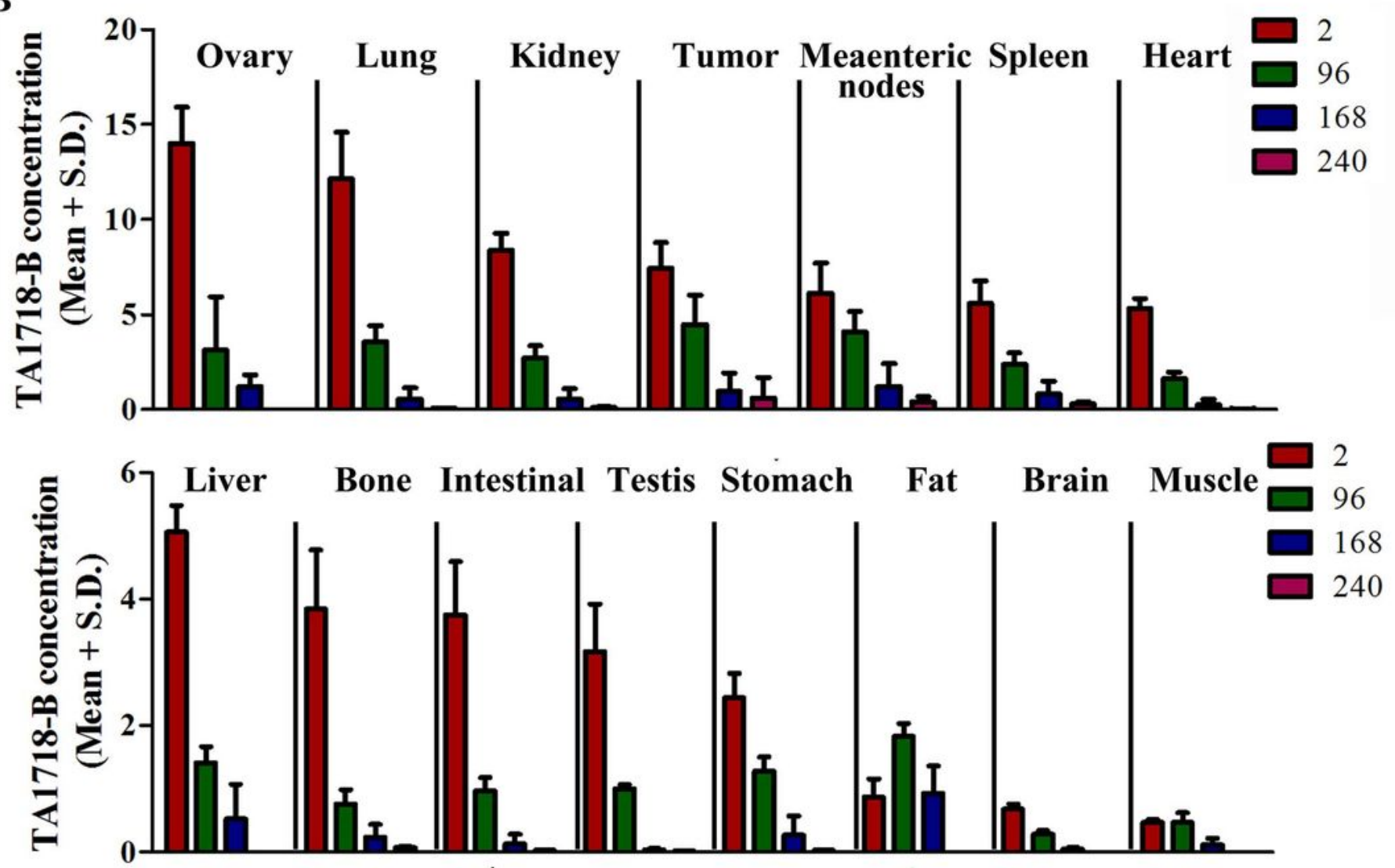

Figure 2

Tissue distribution of TA1718-B in MC38 colon cancer humanized mice after intravenous injection. (A) The heat map represents the concentration of TA1718-B in different tissues of mice injected with 3 $\mathrm{mg} / \mathrm{kg}$ of the mAb. (B) The histogram represents the tissue distributions of TA1718-B in mice. (ND means not detected. $n=6$ per treatment group; results are presented as the mean $\pm S D$ ). 
Figure 3
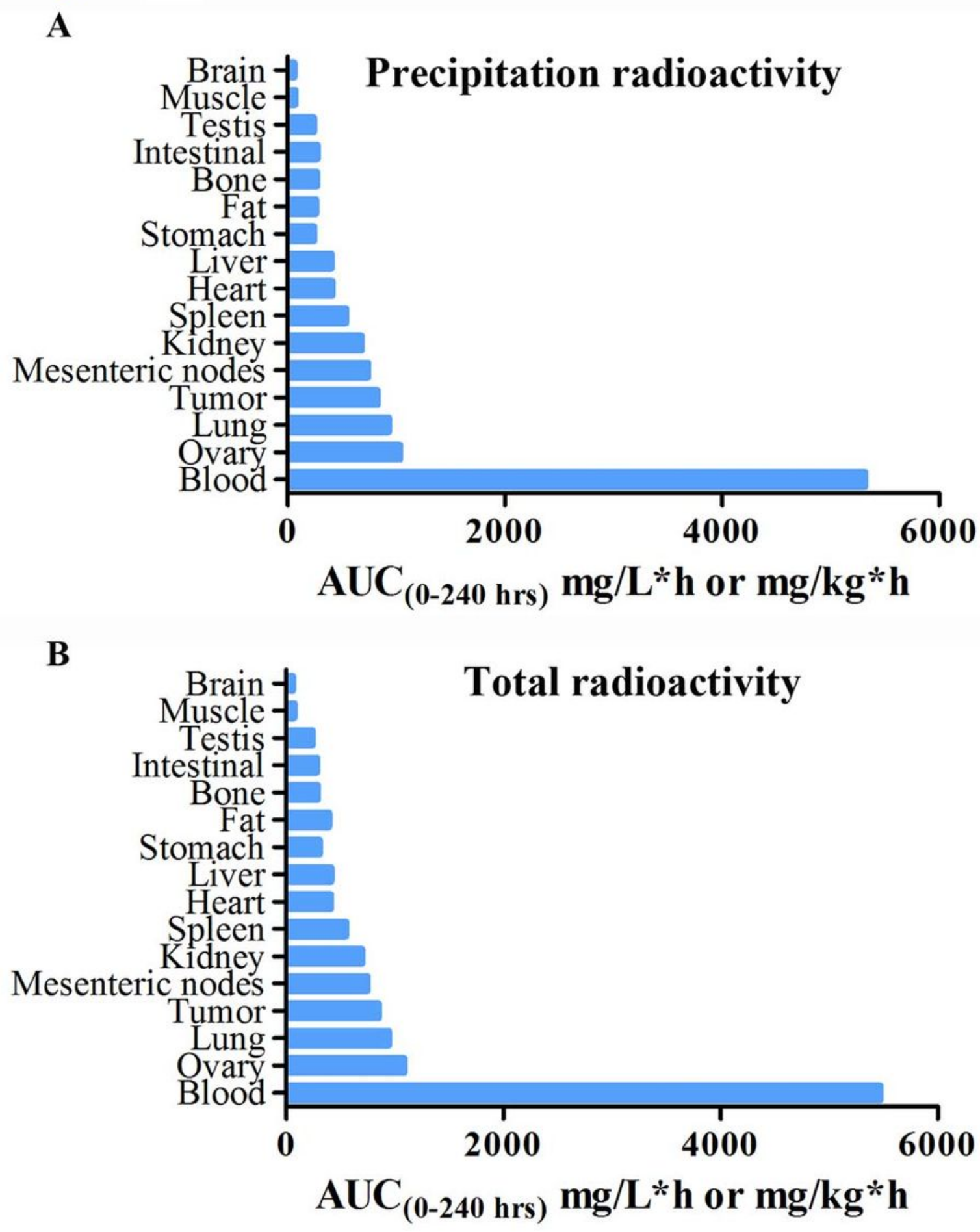

Figure 3

AUC(0-240 hrs) of 125I-TA1718-B in MC38 colon cancer humanized mice after intravenous injection. (A) Precipitation redioactivity of 125I-TA1718-B in different tissues after mice intravenous injected with 3 $\mathrm{mg} / \mathrm{kg}$. (B) Total radioactivity of 125I-TA1718-B in different tissues after mice intravenous injected with 3 $\mathrm{mg} / \mathrm{kg}$ of $\mathrm{mAb}$. 
Figure 4
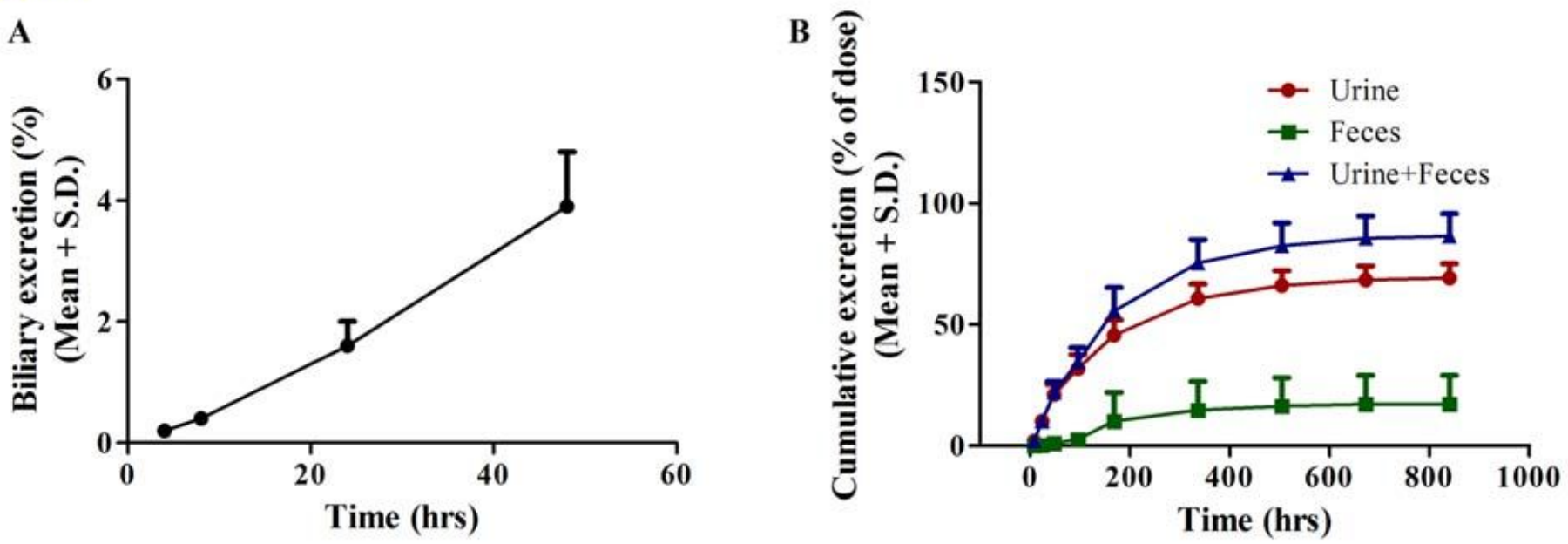

\section{Figure 4}

Accumulative excretions and excretion rate of $125 \mathrm{I}-\mathrm{TA} 1718-\mathrm{B}(30 \mathrm{mg} / \mathrm{kg}$, i.v) on rats in different times. (A) Bile excretion ratio of 125I-TA1718-B in BDC rats. (B) Urine and/or feces excretion ratio of 125I-TA1718-B in $S D$ rats. ( $n=6$ per treatment group; results are presented as the mean $\pm S D$ ).

\section{Supplementary Files}

This is a list of supplementary files associated with this preprint. Click to download.

- arriveguidelineschecklist.docx

- Supplementarymaterial.docx 